\title{
Lateral root initiation in Arabidopsis thaliana: a force awakens
} Joop E. M. Vermeer* and Niko Geldner

Address: Department of Plant Molecular Biology, Biophore Building, UNIL-Sorge, University of Lausanne, 1015 Lausanne, Switzerland

*Corresponding author: Joop E. M. Vermeer (joop.vermeer@unil.ch)

Fl000Prime Reports 2015, 7:32 (doi:10.12703/P7-32)

All F1000Prime Reports articles are distributed under the terms of the Creative Commons Attribution-Non Commercial License (http://creativecommons.org/licenses/by-nc/3.0/legalcode), which permits non-commercial use, distribution, and reproduction in any medium, provided the original work is properly cited.

The electronic version of this article is the complete one and can be found at: http://f1000.com/prime/reports/b/7/32

\begin{abstract}
Osmotically driven turgor pressure of plant cells can be higher than that of a car tire. It puts tremendous forces onto cell walls and drives cell growth and changes in cell shape. This has given rise to unique mechanisms to control organ formation compared to metazoans. The fascinating interplay between forces and local cellular reorganization is still poorly understood. Growth of lateral roots is a prominent example of a developmental process in which mechanical forces between neighboring cells are generated and must be dealt with. Lateral roots initiate from a single cell layer that resides deep within the primary root. On their way out, lateral roots grow through the overlying endodermal, cortical, and epidermal cell layers. It was recently demonstrated that endodermal cells actively accommodate lateral root formation. Interfering genetically with these accommodating responses in the endodermis completely blocks cell proliferation in the pericycle. The lateral root system provides a unique opportunity to elucidate the molecular and cellular mechanisms whereby mechanical forces and intercellular communication regulate spatial accommodation during plant development.
\end{abstract}

\section{A plant's life: development under pressure} Intercellular communication is central for the development of an organism. Beyond biochemical cues, mechanical forces also contribute to the regulation of differentiation and development [1-5]. The ability to sense and respond to mechanical stimuli such as gravity, touch, osmotic pressure, or the resistance of the cell wall is a critical feature of every plant cell. Mechanical forces are not exerted just by the environment; they are intrinsic to all levels of plant architecture [6]. At the tissue level, mechanical stresses are generated when neighboring cell layers exhibit differential extensibility [7].

Unlike mammalian cells, plant cells are non-motile, interconnected through their cell wall, and under considerable turgor pressure. This poses specific problems. How do plant cells deal with the mechanical constraints generated when surrounding cells undergo differential growth? How do these surrounding cells accommodate a newly formed organ? Their physical connection through cell walls facilitates the propagation of mechanical signals arising from pressure differences and differential growth [8]. Plant genomes lack clear homologs of mammalian mechanosensors. This suggests that plants have evolved other mechanisms to perceive and deal with mechanical stresses generated during development. Although we have gained new insights into how this might work on the surface of plants $[2,9,10]$, we still do not know how plants deal with mechanical constraints in inner cell layers and during developmental processes that heavily depend on the responses of surrounding cells.

\section{Lateral root formation: the birth of a new meristem}

A beautiful example of such a process is root branching through the formation of lateral roots. These postembryonically formed organs initiate deep within the primary root and need to grow through to overlying cell layers in order to emerge on the surface of the root. Lateral root formation plays a vital role during plant growth as a branched root system provides a mechanism for the plant to explore the soil for water and nutrients as well as providing anchorage. 
In Arabidopsis thaliana, lateral root formation is a developmental process that is receptive to the intrinsic mechanical constraints imposed by the overlying layers and depends heavily on their accommodating responses [11-14]. Owing to the simple anatomy of Arabidopsis roots, its accessibility for microscopy, and its large genetic toolbox, Arabidopsis lateral root formation has proven to be an excellent model to study pattern formation and organ development in plants. Lateral roots initiate from the pericycle, a cell layer located deep within the primary root, confined between the vascular bundle and the endodermis, necessitating growth through overlying endodermal, cortical, and epidermal cell layers to emerge on the surface of the root (Figure 1) $[4,15,16]$. These features make lateral root formation a perfect model system to study the mechanisms plants have evolved to deal with mechanical constraints to accommodate development. For example, how do the pericycle cells and the primordium overcome the mechanical constraints provided by the surrounding and overlying cells during this process? On the other side, do surrounding and overlying cells accommodate this growing organ and how do they do so? Do all cell layers impose the same mechanical resistance? How important is cell volume control during this process? Recent studies have revealed that mechanical constraints provided by the overlying cell layers play a crucial role during lateral root formation $[11,14,17,18]$. This has added an extra layer of complexity to lateral root

Figure I. Arabidopsis thaliana lateral root initiation

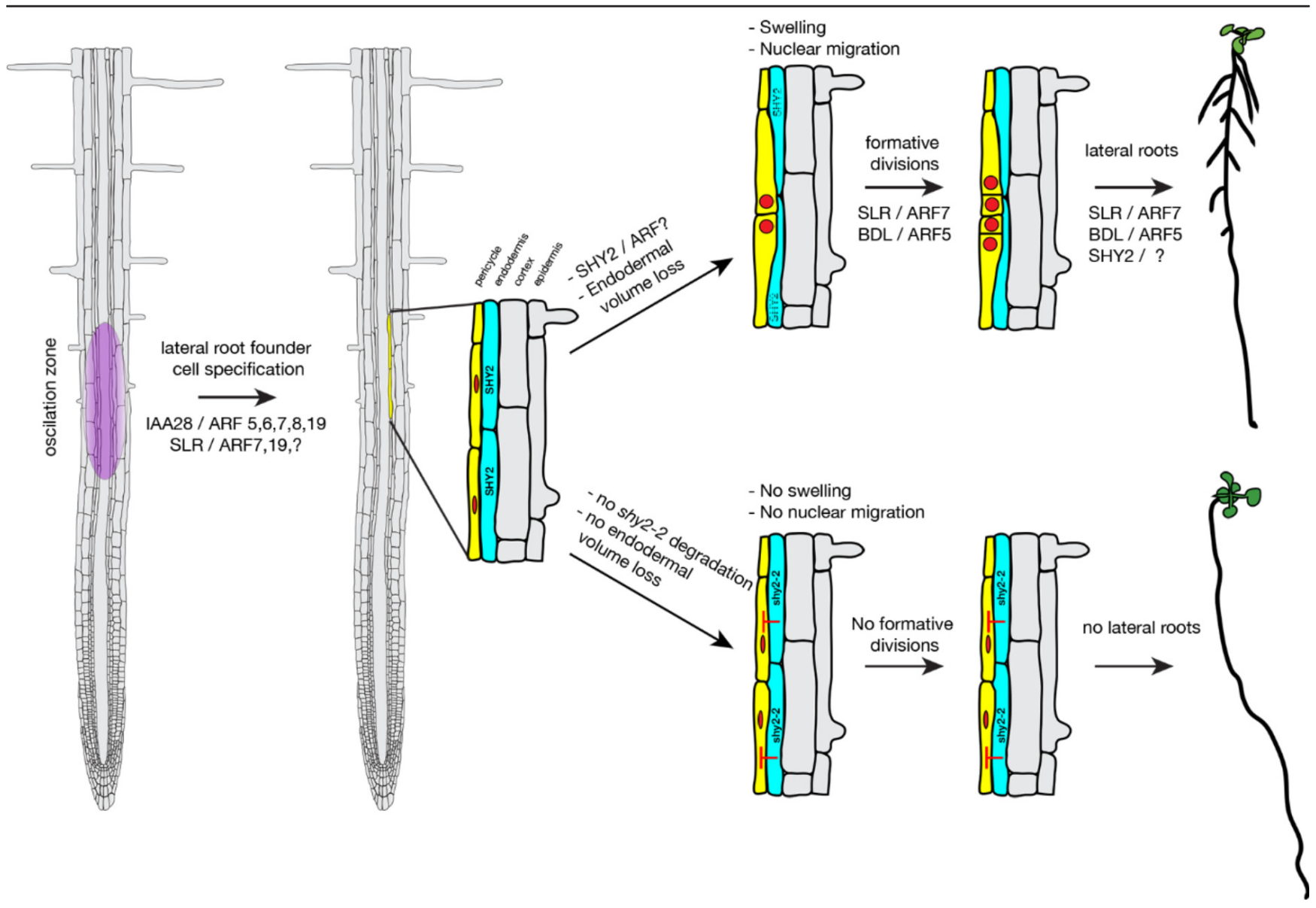

Schematic representation of the different developmental steps of lateral root initiation in Arabidopsis. Lateral root founder cells are primed at the oscillation zone in the basal root meristem. Subsequently, founder cell specification takes place through the IAA28 and IAA I4/SOLITARY ROOT (SLR) auxin signaling modules. Concomitantly, lateral root founder cells increase in volume and their roundup nuclei synchronously migrate to the common cell walls. This process is dependent on endodermal volume loss or shape change mediated by an endodermal SHORT HYPOCOTYL 2 (IAA3/SHY2) auxin signaling module. After formative divisions, different auxin signaling modules, including SLR, IAA I 2/BODENLOS (BDL), and SHY2, and their interacting AUXIN RESPONSE FACTORS (ARFs) mediate the development and emergence of lateral roots, giving rise to a branched root system. Interfering with endodermal volume loss by expressing the stabilized repressor shy2-2 in the endodermis blocks volume increase and nuclear migration in the lateral root founder cells and results in plants without a branched root system. 
development. In this report, we try to integrate these new findings in the model of Arabidopsis lateral root initiation. We will not cover the intriguing aspects of lateral root growth through the overlying cell layers as this was recently covered elsewhere [16].

\section{Preparing for birth: keeping the hormones in check}

As stated above, lateral roots arise from the single-layered pericycle. This cell layer can be divided in two different types of cells: phloem pole and xylem pole pericycle cells. The first displays the feature of differentiated cells, whereas the latter displays the feature of meristematic cells because of their dense cytoplasm and a fragmented vacuole [19]. Lateral roots initiate from asymmetric or formative divisions of triplets of adjacent xylem pole pericycle cells, resulting in a stage I lateral root primordium $[4,15,16]$. However, prior to these formative divisions, the xylem pole pericycle cells need to be specified as lateral root founder cells. Although this has been intensively studied for several years, the precise mechanism that patterns these cells to have the potential to become a lateral root is still not clear [20].

The plant hormone auxin triggers lateral root formation and is essential for the specification of lateral root founder cells. The specification and regular spacing of lateral root founder cells take place in the basal meristem of the root [21-23]. The zone where the xylem pole pericycle cells are specified is also known as the oscillation zone, as it was shown that different auxin signaling reporters displayed recurring expression in this zone that correlated with the occurrence of lateral rootforming competent zones $[21,22]$. It was shown that the oscillations were operating independently of local auxin levels [22]. As the study used a LUCIFERASE-based reporter, the cellular resolution was not sufficient to identify the cell layer(s) and the amount of cells that exhibited oscillating gene expression. As the lateral roots appear to initiate from these cells, it is assumed that they have a xylem pole pericycle identity. Interestingly, oscillations seemed to occur on both xylem poles. Under normal conditions, lateral roots form only at one side of the xylem poles usually followed by an oriented left-right pattern of lateral root formation. Only the cells in the oscillation zone that showed sustained DIRECT REPEAT 5 (DR5)-driven expression developed into a new lateral root, indicating that there is an additional level of regulation between founder cell specification and the transition into the lateral root developmental program. The fact that founder cell specification and lateral root initiation are distinct events was also supported by the observation that the transcriptional oscillation period was shorter than the frequency at which lateral roots initiate $[20,22]$.
The observed oscillation of the auxin signaling reporters in the basal meristem confirmed the importance of auxin signaling in the process of lateral root founder cell specification and the transition to lateral root initiation. It is important to understand that the synthetic DR5 promoter consists of repeats of seven auxin-responsive elements to which the AUXIN RESPONSE FACTOR (ARF) transcription factors bind to activate gene expression [24]. In Arabidopsis, the transcriptional response to auxin by ARFs is modulated by the AUX/IAA repressor proteins that interact and inhibit the ARFs. An increase in the cellular auxin concentration leads to the degradation of the AUX/IAAs, releasing the ARFs from their inhibition and thereby allowing auxin-dependent transcription [25]. In the last few years, several auxin response modules operating at different steps of lateral root formation have been identified [4,26-29].

The plant hormone cytokinin antagonizes the effect of auxin during lateral root initiation as it does in other developmental processes. Through modulation of the cytokinin levels, signaling, or perception, lateral root formation can be severely disturbed. This is thought to be due to cytokinin's effect on auxin transport and homeostasis that is required for the lateral root founder cells to enter mitosis [30-33].

\section{Formative divisions in the pericycle: all needs to be swell}

After the specification, the triplets of adjacent lateral root founder cells undergo asymmetric or formative divisions giving rise to a stage I lateral root primordium. Before they undergo cell division, these cells cannot be distinguished from other pericycle cells without the use of specific reporter lines. Using reporters for auxin signaling or a transcriptional regulator of lateral root founder cell specification, GATA23, it was revealed that prior to formative divisions, the lens-shaped nuclei of founder cells round up and synchronously migrate to the common cell walls [26]. Nuclear migration is tightly linked to lateral root initiation, and several auxin signaling mutants with strong lateral root phenotypes are impaired in this process [26,34]. Besides the involvement of auxin itself, little is known about the underlying mechanism of nuclear migration. Recently, it was reported that Arabidopsis thaliana MYOSIN XI-i (AtMYOSIN XI-i) links the nuclear membrane to the cytoskeleton to control nuclear movement and shape. myosin $x i-i$ mutants showed severely affected nuclear movement and defective darkness-induced nuclear movement [35]. Although this study did not mention anything regarding lateral root initiation, it will be interesting to see whether AtMYOSIN XI- $i$ or other myosins are required for rounding and migration of the nuclei. AtMYOSIN XI-i was linked to the plant actin 
cytoskeleton through interaction with WPP domaininteracting tail-anchored protein 1 (WIT1) and WIT2 [35]. It is surprising that the role of actin organization and dynamics during lateral root initiation (that is, nuclear migration) has been so little explored.

Although most of the visible steps toward formative divisions take place in the lateral root founder cells, recent studies have shown that the direct neighbor, the endodermis, plays an essential role in their progression to the lateral root initiation stage $[14,36]$. First it was reported that a reflux of pericycle-derived auxin between the endodermis and the pericycle assists the progression of lateral root founder cells into lateral roots [36]. This reflux is mediated by the auxin efflux carrier PIN3 since pin 3 mutants showed a delay in the transition from founder cell specification to stage I primordia. Interestingly, PIN3-GFP displayed a polar localization in the plasma membrane of overlying endodermal cells facing the founder cells [36]. Another recent study revealed an even more important role of the endodermis during lateral root initiation. The endodermis contains hydrophobic impregnations of the primary cell wall that fuse into a supracellular network between endodermal cells: the Casparian strips. These impregnations consist of lignin, an inelastic phenolic polymer that is resistant to chemical degradation, making it an extra-resistant cell layer [37-39]. By employing fourdimensional imaging using light-sheet microscopy, it was shown that, concomitantly with nuclear migration, lateral root founder cells increase in volume and that this needs to be accompanied by shrinkage or deformation of the overlying endodermis or both [14]. Interestingly, by expressing the short hypocotyl 2 (shy2)-2 gain-of-function allele of the AUX/IAA IAA3 specifically in elongating endodermal cells to strongly reduce its auxin responsiveness, it was shown that a SHY2-mediated auxin signaling module is essential for lateral root formation [14]. Although lateral root founder cell specification still occurred in these CASP $1_{\text {pro: }}:$ shy2-2 plants, they displayed a complete block of formative divisions, resulting in plants with a complete absence of lateral roots. It was suggested that auxin derived from lateral root founder cells is perceived by the endodermis through a SHY2-dependent auxin signaling module [14]. The endodermis, in turn, needs to signal back to the founder cells to allow them to increase their cell volume and enter mitosis. It appears that the lateral root founder cells in $C A S P 1_{\text {pro }}:: s h y 2-2$ plants perceive the non-responding endodermis as an increased resistance to their expansion growth, resulting in a complete block of lateral root initiation (Figure 1). This revealed for the first time that the direct neighbor of the pericycle, the endodermis, has an essential role in lateral root initiation through accommodating the expanding pericycle cells.

\section{Lateral root initiation: a model to understand the mechanism of spatial accommodation}

The observation that lateral root founder cells need to increase their volume prior to the formative divisions and the necessity of spatial accommodation by the overlying endodermis raises some interesting questions. How do lateral root founder cells swell? How does the endodermis signal back to the pericycle? Does this involve mechanical forces?

A recent study revealed that plant roots use a patterning mechanism to position lateral roots toward available water in the soil, named hydropatterning [40]. This mechanism already affects lateral root formation during founder cell specification. It was shown that hydraulic conductivity from the surface is important for hydropatterning and that auxin transport involving the efflux carrier PIN3 plays an important role [40]. Together with the observation that auxin affects hydrodynamics through the regulation of the function of aquaporins [18], it may well be that aquaporins are involved in the volume increase of lateral root founder cells. In this light, the recently identified pericycle/endodermis interaction provides a good model to understand whether and how plants can establish a differential turgor pressure. Although several studies on lateral root formation suggest that this occurs, the direct evidence is still lacking $[14,18,41]$. The observation that plant cells can regulate the symplastic connections between cells, through the opening and closing of plasmodesmata, provides a new tool to study whether disrupting symplastic connectivity in a cell type-specific manner is required or sufficient for the generation of differential turgor pressure [42]. Indeed, a recent study revealed that lateral roots gradually become symplastically isolated during their development. Interestingly, it was also shown that disruption of the intercellular connectivity of xylem pole pericycle cells through cell type-specific induction of callose deposition disturbed normal lateral root patterning [43]. It would be interesting to see whether this treatment changes the cell size of the xylem pole pericycle cells or whether callose deposition in the cortex or epidermis, layers that are accessible to pressure probes, alters the turgor pressure of the symplastically isolated cells. However, it should be taken into account that massive induction of callose is normally used as a defense mechanism in plants [44], which might complicate the interpretation of the obtained results.

Lateral root initiation is perceptive to mechanical stimuli and it has been shown that this involves a rapid calcium response $[12,45,46]$. The involvement of mechanosignaling is also supported by the observation that the endodermis actively needs to accommodate the swelling 
of the pericycle cells to promote lateral root initiation and that failure to do so completely blocks lateral root formation. As the volume increase might involve changes in turgor pressure, it could be that some mechanosensitive ion channels play an important role in pericycle/ endodermis interaction. Clear candidates would be the homologs of the bacterial mechanosensitive channels of small conductance, such as the MscS-like (MSL) homologs that have been shown to have mechanosensitive activity in Arabidopsis protoplasts. However, plants in which all root-expressed MSL isoforms were knocked out responded to mechanical stress like wild-type plants and did not show any obvious lateral root phenotypes [47]. Another exciting possible candidate is the recently identified reduced hyperosmolality-induced $\left[\mathrm{Ca}^{2+}\right]_{\mathrm{i}}$ increase [4] (OSCA) family that was shown to mediate osmotic stress-evoked $\mathrm{Ca}^{2+}$ increases that are vital for osmosensing in Arabidopsis [48]. This family might prove to be an important player as it might link $\mathrm{Ca}^{2+}$ increase to volume changes during lateral root initiation.

Microtubule organization has been shown to be receptive to changes in mechanical stresses in leaf pavement cells and in the shoot apical meristem $[2,9,10]$. Moreover, the microtubule-severing protein KATANIN was shown to be required for the competence of cells to respond to the mechanical forces generated by growth [10]. Therefore, it would be interesting to visualize microtubule dynamics in xylem pole pericycle cells and the endodermis during lateral root initiation and to test whether KATANIN also plays a role during lateral root initiation.

In the coming years, it will be important to incorporate computational morphodynamics in our studies. To better understand the role of cell volume and cell shapes during lateral root initiation, we need to implement three-dimensional segmentation of root tissues. Recent studies have already shown that this can lead to novel biological insights during plant development $[49,50]$. It will also be important to increase the cell type-specific promoters available in the Arabidopsis toolbox. For example, xylem pole pericycle-specific promoters besides the miR390 and GATA23 promoters $[26,51]$ will be crucial as they will allow better imaging and genetic manipulation of these cells and might reveal novel biological insights as recently shown for the endodermis [14].

\section{Abbreviations}

ARF, AUXIN RESPONSE FACTOR; AtMYOSIN XI-I, Arabidopsis thaliana MYOSIN XI-I; DR5, DIRECT REPEAT 5; MSL, MscS-like; SHY2, SHORT HYPOCOTYL 2; WIT, WPP domain-interacting tail-anchored protein.

\section{Disclosures}

The authors declare that they have no disclosures.

\section{Acknowledgments}

This work was supported by a Marie-Curie Intra-European Fellowship grant to Joop E. M. Vermeer. Supporting grants were from the Swiss National Science Foundation and the European Research Council to Niko Geldner.

\section{References}

I. Carlsbecker A, Lee JY, Roberts CJ, Dettmer J, Lehesranta S, Zhou J, Lindgren O, Moreno-Risueno MA, Vaten A, Thitamadee S, Campilho A, Sebastian J, Bowman JL, Helariutta Y, Benfey PN: Cell signalling by microRNAI65/6 directs gene dose-dependent root cell fate. Nature 2010, 465:316-2I.

\section{FlOOOPrime}

RECOMMENDED

2. Hamant $\mathrm{O}$, Heisler MG, Jonsson H, Krupinski $\mathrm{P}$, Uyttewaal M, Bokov $\mathrm{P}$ Corson F, Sahlin P, Boudaoud A, Meyerowitz EM, Couder Y, Traas J: Developmental patterning by mechanical signals in Arabidopsis. Science 2008, 322: 1650-5.

\section{FlOOOPrime}

\section{RECOMMENDED}

3. Heisenberg CP, Bellaiche Y: Forces in tissue morphogenesis and patterning. Cell 2013, I53:948-62.

4. Lavenus J, Goh T, Roberts I, Guyomarc'h S, Lucas M, De Smet I, Fukaki H, Beeckman T, Bennett M, Laplaze L: Lateral root development in Arabidopsis: fifty shades of auxin. Trends Plant Sci 2013, 18:450-8

5. Schlereth A, Moller B, Liu W, Kientz M, Flipse J, Rademacher EH, Schmid M, Jurgens G, Weijers D: MONOPTEROS controls embryonic root initiation by regulating a mobile transcription factor. Nature 2010, 464:913-6.

FlOOOPrime

RECOMMENDED

6. Monshausen GB, Haswell ES: A force of nature: molecular mechanisms of mechanoperception in plants. J Exp Bot 2013, 64:4663-80.

7. Nakayama N, Smith RS, Mandel T, Robinson S, Kimura S, Boudaoud A, Kuhlemeier C: Mechanical regulation of auxin-mediated growth. Curr Biol 2012, 22: |468-76.

\section{FlOOOPrime}

\section{RECOMMENDED}

8. Boudaoud A: An introduction to the mechanics of morphogenesis for plant biologists. Trends Plant Sci 2010, I 5:353-60.

9. Sampathkumar A, Krupinski P, Wightman R, Milani P, Berquand A, Boudaoud A, Hamant O, Jonsson H, Meyerowitz EM: Subcellular and supracellular mechanical stress prescribes cytoskeleton behavior in Arabidopsis cotyledon pavement cells. Elife 2014, 3:e0 1967.

10. Uyttewaal M, Burian A, Alim K, Landrein B, Borowska-Wykret D, Dedieu A, Peaucelle A, Ludynia M, Traas J, Boudaoud A, Kwiatkowska D, Hamant O: Mechanical stress acts via katanin to amplify differences in growth rate between adjacent cells in Arabidopsis. Cell 2012, 149:439-5I.

II. Lucas M, Kenobi K, von Wangenheim D, Vobeta U, Swarup K, De Smet I, Van Damme D, Lawrence T, Peret B, Moscardi E, Barbeau D, Godin C, Salt D, Guyomarc'h S, Stelzer EH, Maizel A, Laplaze L, Bennett MJ: Lateral root morphogenesis is dependent on the mechanical properties of the overlaying tissues. Proc Natl Acad Sci USA 20 I 3, I I 0:5229-34.

\section{FlOOOPrime}

RECOMMENDED

12. Richter GL, Monshausen GB, Krol A, Gilroy S: Mechanical stimuli modulate lateral root organogenesis. Plant Physiol 2009, | 5 |: | $855-66$. 
13. Swarup K, Benkova E, Swarup R, Casimiro I, Peret B, Yang Y, Parry G, Nielsen E, De Smet I, Vanneste S, Levesque MP, Carrier D, James N, Calvo V, Ljung K, Kramer E, Roberts R, Graham N, Marillonnet S, Patel K, Jones JD, Taylor CG, Schachtman DP, May S, Sandberg G, Benfey P, Friml J, Kerr I, Beeckman T, Laplaze L, Bennett MJ: The auxin influx carrier LAX3 promotes lateral root emergence. Nat Cell Biol 2008, 10:946-54.

\section{FlOOOPrime}

14. Vermeer JE, von Wangenheim D, Barberon M, Lee Y, Stelzer EH, Maizel A, Geldner N: A spatial accommodation by neighboring cells is required for organ initiation in Arabidopsis. Science 2014, 343:178-83.

\section{FlOOOPrime} RECOMMENDED

15. Peret B, De Rybel B, Casimiro I, Benkova E, Swarup R, Laplaze L, Beeckman T, Bennett MJ: Arabidopsis lateral root development: an emerging story. Trends Plant Sci 2009, 14:399-408.

16. Vilches-Barro A, Maizel A: Talking through walls: mechanisms of lateral root emergence in Arabidopsis thaliana. Curr Opin Plant Biol 2014, 23:31-38

17. Kumpf RP, Shi CL, Larrieu A, Sto IM, Butenko MA, Peret B, Riiser ES, Bennett MJ, Aalen RB: Floral organ abscission peptide IDA and its HAE/HSL2 receptors control cell separation during lateral root emergence. Proc Natl Acad Sci USA 20 I3, I 1 0:5235-40.

18. Peret B, Li G, Zhao J, Band LR, Voss U, Postaire O, Luu DT, Da Ines O, Casimiro I, Lucas M, Wells DM, Lazzerini L, Nacry P, King JR, Jensen OE, Schaffner AR, Maurel C, Bennett M]: Auxin regulates aquaporin function to facilitate lateral root emergence. Natt Cell Biol 2012, 14:99|-8.

19. Parizot B, Laplaze L, Ricaud L, Boucheron-Dubuisson E, Bayle V, Bonke M, De Smet I, Poethig SR, Helariutta Y, Haseloff J, Chriqui D, Beeckman T, Nussaume L: Diarch symmetry of the vascular bundle in Arabidopsis root encompasses the pericycle and is reflected in distich lateral root initiation. Plant Physiol 2008, 146: I40-8.

\section{FlOOOPrime}

20. Van Norman JM, Xuan W, Beeckman T, Benfey PN: To branch or not to branch: the role of pre-patterning in lateral root formation. Development 2013, 140:4301-10.

21. De Smet I, Tetsumura T, De Rybel B, Frey NF, Laplaze L, Casimiro I, Swarup R, Naudts M, Vanneste S, Audenaert D, Inze D, Bennett MJ, Beeckman T: Auxin-dependent regulation of lateral root positioning in the basal meristem of Arabidopsis. Development 2007, 134:681-90.

\section{FlOOOPrime}

\section{RECOMMENDED}

22. Moreno-Risueno MA, Van Norman JM, Moreno A, Zhang J, Ahnert SE, Benfey PN: Oscillating gene expression determines competence for periodic Arabidopsis root branching. Science 2010, 329: I306-II.

\section{FlOOOPrime \\ RECOMMENDED}

23. Van Norman JM, Zhang J, Cazzonelli Cl, Pogson BJ, Harrison PJ, Bugg TD, Chan KX, Thompson AJ, Benfey PN: Periodic root branching in Arabidopsis requires synthesis of an uncharacterized carotenoid derivative. Proc Natl Acad Sci USA 20I 4, I I I:EI300.

\section{FlOOOPrime} RECOMMENDED

24. Ulmasov T, Murfett ], Hagen G, Guilfoyle T]: Aux/IAA proteins repress expression of reporter genes containing natural and highly active synthetic auxin response elements. Plant Cell 1997, 9:1963-71.

25. Lokerse AS, Weijers D: Auxin enters the matrix-assembly of response machineries for specific outputs. Current Opin Plant Biol 2009, I 2:520-6.

26. De Rybel B, Vassileva V, Parizot B, Demeulenaere M, Grunewald W, Audenaert D, Van Campenhout J, Overvoorde P, Jansen L, Vanneste S,
Moller B, Wilson M, Holman T, Van Isterdael G, Brunoud G, Vuylsteke M, Vernoux T, De Veylder L, Inze D, Weijers D, Bennett M], Beeckman T: A novel aux/IAA28 signaling cascade activates GATA23-dependent specification of lateral root founder cell identity. Curr Biol 2010, 20:1697-706.

27. De Smet I, Lau S, Voss U, Vanneste S, Benjamins R, Rademacher EH, Schlereth A, De Rybel B, Vassileva V, Grunewald W, Naudts M, Levesque MP, Ehrismann JS, Inze D, Luschnig C, Benfey PN, Weijers D, Van Montagu MC, Bennett MJ, Jurgens G, Beeckman T: Bimodular auxin response controls organogenesis in Arabidopsis. Proc Natl Acad Sci USA 2010, 107:2705-10.

28. Goh T, Kasahara H, Mimura T, Kamiya Y, Fukaki H: Multiple AUX/ IAA-ARF modules regulate lateral root formation: the role of Arabidopsis SHY2/IAA3-mediated auxin signalling. Philos Trans $R$ Soc Lond B Biol Sci 2012, 367:146I-8.

29. Okushima $Y$, Fukaki $H$, Onoda $M$, Theologis $A$, Tasaka M: ARF7 and ARF I 9 regulate lateral root formation via direct activation of LBD/ASL genes in Arabidopsis. Plant Cell 2007, 19:I I8-30.

30. Bielach A, Podlesakova K, Marhavy P, Duclercq J, Cuesta C, Muller B, Grunewald W, Tarkowski P, Benkova E: Spatiotemporal regulation of lateral root organogenesis in Arabidopsis by cytokinin. Plant Cell 2012, 24:3967-8I.

31. Chang L, Ramireddy E, Schmulling T: Lateral root formation and growth of Arabidopsis is redundantly regulated by cytokinin metabolism and signalling genes. J Exp Bot 20I3, 64:502I-32.

32. Laplaze L, Benkova E, Casimiro I, Maes L, Vanneste S, Swarup R, Weijers D, Calvo V, Parizot B, Herrera-Rodriguez MB, Offringa R, Graham N, Doumas P, Friml J, Bogusz D, Beeckman T, Bennett M: Cytokinins act directly on lateral root founder cells to inhibit root initiation. Plant Cell 2007, 19:3889-900.

33. Marhavy P, Duclercq J, Weller B, Feraru E, Bielach A, Offringa R, Friml J, Schwechheimer C, Murphy A, Benkova E: Cytokinin controls polarity of PINI-dependent auxin transport during lateral root organogenesis. Curr Biol 20I4, 24:103।-7.

34. Goh T, Joi S, Mimura T, Fukaki H: The establishment of asymmetry in Arabidopsis lateral root founder cells is regulated by LBDI6/ASLI8 and related LBD/ASL proteins. Development 2012, 139:883-93.

35. Tamura K, Iwabuchi K, Fukao $\mathrm{Y}$, Kondo M, Okamoto K, Ueda $\mathrm{H}$ Nishimura M, Hara-Nishimura I: Myosin XI-i links the nuclear membrane to the cytoskeleton to control nuclear movement and shape in Arabidopsis. Curr Biol 2013, 23:1776-8I.

36. Marhavy P, Vanstraelen M, De Rybel B, Zhaojun D, Bennett MJ, Beeckman T, Benkova $E$ : Auxin reflux between the endodermis and pericycle promotes lateral root initiation. EMBO J 2013, 32: I49-58.

37. Lee Y, Rubio MC, Alassimone J, Geldner N: A mechanism for localized lignin deposition in the endodermis. Cell 2013, I53:402-12.

\section{FlOOOPrime}

\section{RECOMMENDED}

38. Naseer S, Lee $Y$, Lapierre C, Franke R, Nawrath C, Geldner N: Casparian strip diffusion barrier in Arabidopsis is made of a lignin polymer without suberin. Proc Natl Acad Sci USA 2012, 109:10101-6.

39. Roppolo D, De Rybel B, Tendon VD, Pfister A, Alassimone J, Vermeer JE, Yamazaki M, Stierhof YD, Beeckman T, Geldner N: A novel protein family mediates Casparian strip formation in the endodermis. Nature 20II, 473:380-3.

40. Bao Y, Aggarwal P, Robbins NE, 2nd, Sturrock C), Thompson MC, Tan HQ, Tham C, Duan L, Rodriguez PL, Vernoux T, Mooney SJ, Bennett MJ, Dinneny JR: Plant roots use a patterning mechanism to position lateral root branches toward available water. Proc Natl Acad Sci USA 2014, I I I:9319-24.

\section{FlOOOPrime}

4I. Beauzamy L, Nakayama N, Boudaoud A: Flowers under pressure: ins and outs of turgor regulation in development. Ann Bot 2014, II 14:1517-33.

42. Vaten A, Dettmer J, Wu S, Stierhof YD, Miyashima S, Yadav SR, Roberts CJ, Campilho A, Bulone V, Lichtenberger R, Lehesranta S, 
Mahonen AP, Kim JY, Jokitalo E, Sauer N, Scheres B, Nakajima K, Carlsbecker A, Gallagher KL, Helariutta Y: Callose biosynthesis regulates symplastic trafficking during root development. Dev Cell 20II, 2 I: I | 44-55.

\section{FlOOOPrime \\ RECOMMENDED}

43. Benitez-Alfonso $Y$, Faulkner C, Pendle A, Miyashima S, Helariutta $Y$, Maule A: Symplastic Intercellular Connectivity Regulates Lateral Root Patterning. Dev Cell 20I3, 26:136-47.

\section{FlOOOPrime

RECOMMENDED

44. Ellinger D, Voigt CA: Callose biosynthesis in arabidopsis with a focus on pathogen response: what we have learned within the last decade. Ann Bot 2014, I | 4: 1349-58.

45. Ditengou FA, Teale WD, Kochersperger P, Flittner KA, Kneuper I, van der Graaff E, Nziengui H, Pinosa F, Li X, Nitschke R, Laux T, Palme K: Mechanical induction of lateral root initiation in Arabidopsis thaliana. Proc Natl Acad Sci USA 2008, 105: 188|8-23.

46. Vincill ED, Clarin AE, Molenda JN, Spalding EP: Interacting glutamate receptor-like proteins in Phloem regulate lateral root initiation in Arabidopsis. Plant Cell 2013, 25: I304-13.

\section{FlOOOPrime}

\section{RECOMMENDED}

47. Haswell ES, Peyronnet R, Barbier-Brygoo H, Meyerowitz EM, Frachisse JM: Two MscS homologs provide mechanosensitive channel activities in the Arabidopsis root. Curr Biol 2008, I8:730-4.

\section{FlOOOPrime}

48. Yuan F, Yang H, Xue Y, Kong D, Ye R, Li C, Zhang J, Theprungsirikul L, Shrift T, Krichilsky B, Johnson DM, Swift GB, He Y, Siedow JN, Pei ZM: OSCAI mediates osmotic-stress-evoked $\mathrm{Ca} 2+$ increases vital for osmosensing in Arabidopsis. Nature 20 I4, 5 I 4:367-7I.

\section{FlOOOPrime}

\section{RECOMMENDED}

49. Bassel GW, Stamm P, Mosca G, Barbier de Reuille P, Gibbs DJ, Winter R, Janka A, Holdsworth MJ, Smith RS: Mechanical constraints imposed by 3D cellular geometry and arrangement modulate growth patterns in the Arabidopsis embryo. Proc Natl Acad Sci USA 2014, II I:8685-90.

50. Yoshida S, Barbier de Reuille P, Lane B, Bassel GW, Prusinkiewicz P, Smith RS, Weijers D: Genetic control of plant development by overriding a geometric division rule. Dev Cell 20I4, 29:75-87.

5I. Marin E, Jouannet V, Herz A, Lokerse AS, Weijers D, Vaucheret H, Nussaume L, Crespi MD, Maizel A: miR390, Arabidopsis TAS3 tasiRNAs, and their AUXIN RESPONSE FACTOR targets define an autoregulatory network quantitatively regulating lateral root growth. Plant Cell 2010, 22: I 104-I7. 